\title{
An Analysis of the Present Situation of MOOC and Its Enlightenment to College English Teaching in Application-oriented Colleges and Universities*
}

\author{
Huijun $\mathrm{Yu}$ \\ Anhui Sanlian University \\ Anhui, China 230601
}

\begin{abstract}
In recent years, MOOC has developed rapidly and attracted wide attention from various universities, governments and the public. MOOC can not only promote the transformation of education mode in colleges and universities, but also make full use of high-quality teaching resources. At present, the teaching resources of the application-oriented universities are relatively weak, and the teaching models and methods need to be updated. It can be seen that MOOC has great significance to it. In addition, the construction of college English courses in application-oriented universities is not of high quality, which cannot fully reflect the goal of talent training, and MOOC can effectively improve this situation. Through the analysis of the present situation of the development of MOOC, this paper expounds the impact and challenge it brings to the application-oriented universities, and then puts forward the enlightenment of MOOC to the application-oriented universities in college English teaching.
\end{abstract}

Keywords-MOOC; application-oriented colleges and universities; college English teaching

\section{INTRODUCTION}

The term MOOC was first proposed in 2008. 2012 is called the "first year of MOOC", when breakthrough was made. Three major platforms for MOOC including Coursera, Udacity and edX are set up. MOOC is a kind of generative curriculum of which the content extends and expands with the development of the curriculum. The reason why it is called "large-scale open online courses" is that it is in line with the new trend of large scale and big data. MOOC focuses on the large-scale number of learners, the scientific analysis of big data, and the large-scale sharing of educational resources. In recent years, the rapid development of MOOC has brought certain influence to the higher education circles at home and abroad, and can effectively enhance students' interest and participation in learning. However, there are inadaptability and limitations in the development of MOOC in China. Therefore, based on the current situation of the relative scarcity of teaching resources in application-oriented universities, how should its college English teaching model take its essence and remove its dross?

*Fund Project: This paper is the phased achievement of the large-scale online open course (MOOC) demonstration project "Business English Negotiation" in Anhui Sanlian University. Project number: 16zlgc020.

\section{CuRRENT Situation OF DEVElopMENT OF MOOC}

Coursera, Udacity and edX are the three major MOOC providers that offer high-quality video courses to learners on their platforms, in collaboration with the world's leading colleges and universities, to enable learners to learn knowledge online. Some famous universities in China have joined these three platforms, such as Tsinghua University, Peking University, Fudan University and Shanghai Jiaotong University. In order to adapt to the tide of globalization, some excellent learning platforms have been created in China, such as the three public MOOC platforms of "Good University Online", "Chinese University MOOC" and "School Online". These domestic MOOC platforms now have a very large number of registered users, and the number of learners of an excellent course even can reach more than 100,000 .

Therefore, what is it that makes MOOC so responsive? What are the advantages and characteristics of MOOC? First of all, from the point of view of curriculum time, the original one-hour curriculum is divided into about six short units by MOOC, so that students can study independently and selectively to learn knowledge pertinently without wasting time. Second, there is no upper limit on the number of participants of MOOC. MOOC has largely changed the traditional classroom-based learning approach, and offered courses of top-notch university to students around the world. Thirdly, MOOC has expansibility. Stephen Downes and George Siemens once conceived MOOC as an ecosystem of "connectionism." The theory of connectionism holds that knowledge is no longer the ultimate goal, but an ongoing activity. Through the learning of MOOC, learners can not only acquire knowledge in learning activities, but also construct new knowledge and produce new ideas. In addition, MOOC has the strong interaction and interestingness. Instead of sitting around and watching videos, students actually learn and understand the content of the course by practicing the material. Learners need to complete the retrospective test after the study of each part and they can continue to watch the next part if they give the correct answer. They will be informed the error if they give the wrong answer. This test is similar to game, which brings to the learners a certain amount of interest when they are 
learning. At present, learners can not only learn the courses they are interested in on the learning platform, but also obtain the corresponding credits through the study of the platform courses.

At the same time, the development of MOOC is also facing enormous challenges. Due to the very low completion rate of the curriculum, MOOC encounters a lot of criticism and doubt. The completion rate of the courses chosen by MOOC learners is less than $10 \%$ on average, and such completion rate limits the role of MOOC in educational quality reform and educational research to a certain extent. In addition, the current MOOC teachers are mainly outstanding teachers in key colleges or professors of specialties. Although they can ensure the quality of the courses, it is difficult to teach students in accordance with their aptitude, which is not completely advantageous to the sharing of resources.

Therefore, in order to better adapt to the current environment of China's development, and be in line with the direction of the development of higher education in China, MOOC still needs to make some changes; On the basis of the inherent advantages of MOOC, it should increase the learning strategies adapted to our students and renew the existing excellent teaching methods and models.

\section{THE IMPACT OF MOOC ON APPLICATION-ORIENTED UNDERGRADUATE COLLEGES AND UNIVERSITIES}

\section{A. MOOC Breaks the Restrictions of Learners' Time and Space}

At present, MOOC learners with mobile phones, computers and networks can learn high-quality online courses of world-famous universities at any time and any place in the world. The rise and development of MOOC has pushed down the "fence" of universities and lifted the restrictions on regions, academic credentials and countries. In addition, MOOC also provides opener learning opportunities, and creates more practical learning opportunities for students with relatively poor families. Therefore, to a certain extent, some learners prefer to study the courses of the world famous schools through simple registration and obtain the study certificates of the famous schools, rather than pay the tuition to the physical universities, especially the general application-oriented colleges and universities which are relatively ordinary in teaching quality and conditions.

\section{B. MOOC Has More Abundant Teaching Resources}

This platform provides a large number of courses of outstanding teacher for learners, including humanities, social sciences, natural sciences, politics, economics, and law and so on. Course elements are complete, including learning objectives, interaction between teachers and students, video exercises, homework, evaluation of learning results and proof of results. The teaching mode of MOOC is reasonable, the teaching resources are rich and the quality is high. Besides, the distribution of course time is reasonable and flexible, which is beneficial to learners' selective learning and does not waste time. Therefore, MOOC is praised highly by many learners.

By contrast, the teaching resources of applicationoriented universities are relatively weak. As far as college English teaching is concerned, English teachers are relatively weak. Although the introduction of talents in colleges and universities has increased in recent years, the overall distribution of talents is still imbalance. The proportion of high-level talents is relatively low, and the difference is significant compared with the national key colleges and universities In addition, the construction quality of college English courses in application-oriented colleges and universities is not high. The main reason lies in the inaccurate course construction orientation, unclear standard, and insufficient investment in the construction of teaching resources; college English class hours cannot be guaranteed; the content of the textbook is old and tedious, and the content of the course cannot reflect the practicality and application, so it is difficult to improve the students' learning interest and application ability.

\section{The Teaching Mode of MOOC Is Opener and More Interactive}

One of the basic features of MOOC is openness. The MOOC platform does not limit the number of registered students, supports life-long education, and does not set any threshold for learners. At the same time, the interactive teaching mode of MOOC helps to break the traditional indoctrination teaching mode. When realizing the sharing of high-quality teaching resources, it can also set shorter teaching time according to the characteristics of online learning. There are questions, answers and discussions in the teaching process. Learners can ask questions at any time in the classroom and get instant responses from teachers and other learners. The interaction is very strong, so it can better stimulate learners' interest in learning and realize interactive teaching.

At present, the teaching model of application-oriented universities is still centered on teachers. Textbooks are the main content of teaching. There is less interaction between teacher and students and the teaching mode of cramming education is still visible, which is difficult to mobilize students' enthusiasm for learning, so that students will fall into continuous passive learning. In addition, the courses taught by some teachers are relatively fixed. The contents taught in several years remain the same, the knowledge and teaching methods are updated slowly, and the personal improvement of teachers is also relatively slow. Therefore, the current teaching model in the application-oriented universities cannot fully realize openness and interaction.

\section{ENLIGHTENMENT OF MOOC ON COLLEGE ENGLISH TEACHING IN APPLICATION-ORIENTED UNIVERSITIES}

\section{A. Constructing a Mode of Autonomous English Learning for College Students}

Independent study of college students is not the same as self-study, and their learning effects will be directly affected 
by schools and teachers. As far as the school level is concerned, the teaching model should be reformed first, and the traditional teaching model should be taken as a necessary supplement to the comprehensive teaching model. The teachers can guide students to study independently before class, during the lesson, students should actively explore and participate in discussions with classmates and teachers, and after class they can summarize to consolidate. The second is to provide the necessary financial support and build a platform for MOOC. We can provide appropriate foreign language learning equipment and network environment, create conditions for students to carry out independent study, and provide the best quality English education resources in line with the school's talent training program.

At the teacher level, teachers need to change their teaching concepts, continuously improve their professional and technical skills, enrich and follow new professional knowledge, carefully organize classroom teaching, increase classroom interactions, guide students to learn English independently, and cultivate students' ability to actively construct knowledge.

\section{B. Construction of Professional English Curriculum Resources}

The textbooks used in English general education for application-oriented universities are mainly New Horizons College English and New Experience College English, which include the content of listening, speaking, reading, writing and translating. However, it is not very specific to the majors, and the application-oriented undergraduate colleges need to develop international specialized talents who not only possess the professional knowledge of certain fields but also have certain professional English use and expression capabilities. Therefore, professional English education is urgently needed. Making full use of MOOC and combining modern teaching methods can help application-oriented universities to achieve the goal of cultivating the comprehensive application talents to the largest extent.

It is worth noting that the current construction of professional English textbooks for application-oriented universities lags behind, the teaching methods and teaching tasks are in a single form, and there is a lack of coherence between curriculum units. The annotation of technical terms is not clear, and there is no suitable supporting practice. All these can show that most professional college English teaching in application-oriented universities can't meet the needs of students' language knowledge and skills development. In addition, although most college English teachers have solid basic teaching skills, the knowledge structure is relatively simple. There are few teachers who have professional English research backgrounds, and their ability is not equal to their ambition in teaching professional English, so they are unable to understand the related background knowledge and case studies. Therefore, according to the professional situation set by the school, we must develop targeted English courses, such as tourism English, traffic English, ceramic English, and legal English. We can make full use of the advantages of MOOC platform to form a team of MOOC teachers in the school, and share the advantages of resources through inter-school cooperation to create MOOC with the characteristics of applicationoriented universities. This is also conducive to the development and updating of professional English textbooks and the construction of professional teachers.

\section{Combining MOOC with Flipped Classroom}

As a new teaching method, MOOC can stimulate learners' interest in learning and increase their participation. Application-oriented colleges and universities can build a platform for MOOC, combine multimedia to assist teaching, and implement flipped classroom teaching. That is to say, they can take teacher's classroom teaching as the main method to improve students' interest in learning by combining MOOC and flipped classroom, which can also cultivate students' self-learning ability and truly achieve the organic combination of classroom teaching and online selflearning. In college English teaching, teachers can assign students pre-class tasks and require students to watch the teacher's video before class. After watching the video, the students sum up the difficult points in the video, discuss and solve the problems together with the teachers and classmates in the classroom. Through the consolidation in the classroom, the knowledge can be internalized, and the learning efficiency is greatly improved. In this process, the teacher's role is to guide the students how to learn; students are the main body, and constantly improve the independence and autonomy of their own English learning. The combination of MOOC and flipped classroom is conducive to the student's self-control of learning rhythm, which is conducive to the overall improvement of teacher-student and student-student interaction.

\section{Using MOOC to Improve the Teacher Evaluation System}

The appraisal system for teachers in application-oriented universities is relatively single and incomplete. In the evaluation of teachers' job title, teachers' teaching and research capabilities and scientific research capabilities are highly valued while teachers' teaching ability and innovation ability are weakened. This has led the stagnation of teachers' the teaching ability to a certain degree and decreased attention to teaching. Therefore, application-oriented universities should encourage teachers to combine the school's characteristics and personnel training objectives to build MOOC, formulate development plans for MOOC, and provide financial support, so that advanced teaching models and ideas can be continuously imported into the teaching staff. In this way, the teachers in the MOOC production team can have a certain amount of extra points in terms of job title evaluation and appraisal, which can improve teachers' ability to enhance self-teaching and actively participate in MOOC construction.

\section{CONCLUSION}

The development of MOOC is still one of the hot spots in education circle today. MOOC brings a new atmosphere to college teaching, and puts forward higher requirements for college classroom teaching models, which not only helps teachers to change the traditional role of classroom teaching, 
but also helps students to fully play the dominant role and implement the teaching value orientation of "learning" as the basis. MOOC platform has its unique advantages, which are mainly manifested in its openness, self-selectivity of learning methods, and extensibility, interactivity and high quality of curriculum resources. This is also the reason why the development of MOOC has been rapid in recent years. However, MOOC is not perfect, and criticism and question of MOOC follow. The quality of the course, the completion rate, and the specific requirements for the faculty are important issues in the development of MOOC. In addition, the main leaders and main beneficiaries of MOOC are still mainly top universities at home and abroad which have the core discourse power and resources, while relatively underused application-oriented colleges and universities are subjected to great impact and challenges in this education reform. Therefore, application-oriented universities should meet the challenges with a positive attitude. This paper takes college English teaching as an example, and puts forward that students need to construct English independent study mode; teachers should update teaching idea and teaching methods and perfect teaching mode; schools need to build professional English curriculum resources, and build the MOOC with the characteristics of application-oriented undergraduates according to professional requirements and talent training objectives. In addition, "flipped classroom" and MOOC can be combined to be an important supplement to classroom teaching relying on the Internet platform, which can greatly improve the efficiency of classroom teaching. Finally, through MOOC we can further improve the teacher evaluation system and allow more teachers to participate in the construction of MOOC, so that they can promotes the development of MOOC when improving them.

At present, the development of MOOC is still not mature enough, and its actual impact and role remain to be examined. What we can do is to focus on and explore the problems that arise in the development and face and improve it with a positive attitude. Under the background of the education reform brought about by MOOC, the application-oriented colleges and universities can only develop characteristics, make reasonable position, change the teaching mode, and update the teaching idea to keep up with the current trend of education progress and development.

\section{REFERENCES}

[1] Henry C. Lucas, Jr. Can the Current Model of Higher Education Survive [J]Educause Review, 2013(9):54-66.

[2] Laura Pappano. The Year of the MOOC [N]. The New York Times, 2013.

[3] Chen Lin, Tang Yiqian, Zhou Mingsheng. Difficulties and Countermeasures of Curriculum Construction of Application-oriented Colleges and Universities in the Era of MOOC [J]. Chinese University Teaching, 2015 (4): 51-53. 陈琳, 唐毅谦, 周明圣. 慕课 时代应用型本科院校课程建设的困难与对策 $[\mathrm{J}]$. 中国大学教学, 2015 (4) : 51-53

[4] Du Yang. Five Challenges of "MOOC" to the University System [EB/OL].

http://www.edu.cn/gao_jiao_news_367/20130821/t20130821_100408 6.shtml，2013-08-21. 杜杨. “慕课” 对高校体制的五大挑战 [EB/OL]. http://www.edu.cn/gao_jiao_news_367/20130821/t20130821_100408 6.shtml, 2013-08-21.

[5] Liu Yan, Kong Lingjun. Development of curriculum resources for higher education in the United States and its enlightenment [J]. Shaanxi Radio and Television University Journal, 2016 (3): 27-30. 刘 艳, 孔令军. 美国高等教育课程资源开发及启示 [J]. 陕西广播电 视大学学报, 2016 (3) :27-30.

[6] Wang Rong. Development and challenges of MOOC at abroad [J]. Journal of World Education, 2014 (14): 8-11. 王蓉. 国外慕课的发展 与面临的挑战（下） [J]. 世界教育信息, 2014 (14)：8-11.

[7] Xu Yanqing. Enlightenment of MOOC teaching to college English teaching in application-oriented universities $[\mathrm{J}]$. Education Modernization, 2017 (26): 140-141. 许艳青. 慕课 (MOOC) 教学 对应用型本科院校大学英语教学的启示 [J]. 教育现代化, 2017 (26) :140-141.

[8] Zhang Shanshan, Yan Yajun, Li Suzhi. Impact of MOOC on application-oriented universities and its countermeasures [J]. Journal of North China Institute of Aerospace Engineering, 2014 (24): 45-48. 张珊珊, 间亚军, 李素枝. 慕课对应用型本科院校的冲击与应对 策略[J]. 北华航天工业学院学报, 2014 (24) : 45-48.

[9] Zhang Zhiyuan. Influence of development of MOOC on China's higher education and its countermeasures [J]. Journal of Hebei Normal University, 2014 (16): 116-121. 张鸷远. “慕课” (MOOCs) 发展对我国高等教育的影响及其对策 [J]. 河北师范 大学学报, 2014 (16)：116-121. 